\title{
IDENTIFIKASI PENYAKIT JATI (TECTONA GRANDIS) DAN AKASIA (ACACIA AURICULIFORMIS) DI HUTAN RAKYAT KABUPATEN WONOGIRI, JAWA TENGAH
}

Diseases Identification in Teak (Tectona grandis) and Acacia (Acacia auriculiformis) in Community Forest of Wonogiri District, Central Java

\author{
Burhan Ismail ${ }^{1)}$ dan Illa Anggraeni ${ }^{2)}$ \\ ${ }^{1}$ Balai Besar Penelitian Bioteknologi dan Pemuliaan Tanaman Hutan, Yogyakarta \\ ${ }^{2}$ Pusat Penelitian dan Pengembangan Hutan Tanaman, Bogor
}

\begin{abstract}
Since the regreening project launched by presidential decree in 1976/1977 and the movement of National Land and Forest Rehabilitation (GNRHL) in 2003, community forest plantation area is increasing and inclined to be more independent in their plantation management. In Wonogiri district the community forest achieve the total area of 27.433 hectare, spreaded out in 25 subdistricts. Disease on forest plantation is one of factors that causing significant risk and has to be tackled seriously. The objective is to identify plant disease (particularly on Teak and Acacia) in community forest of Wonogiri district, Central Java. This is a preliminary study to determine further strategy in disease management. The result showed that teak plants were attacked by bacteria of Pseudomonas tectonae (Ralstonia solanacearum). While Acacia were attacked by fungi of Meliola sp., Atelocauda digitata and Oidium sp., the three fungus attacked Acacia are obligate parasitic.
\end{abstract}

Key Words : Acacia disease, community forest, disease identification, teak disease

\begin{abstract}
ABSTRAK
Sejak adanya "Proyek Inpres Penghijauan" tahun 1976/1977 dan program "Gerakan Nasional Rehabilitasi Hutan dan Lahan" (GNRHL/Gerhan) pada tahun 2003, kegiatan penanaman hutan rakyat semakin marak dan sampai saat ini berkembang menjadi hutan swadaya. Di Kabupaten Wonogiri luas hutan rakyat pada tahun 2005 mencapai 27.433 hektar yang tersebar di 25 kecamatan. Pada setiap pengusahaan hutan rakyat ada resiko terjadi serangan penyakit. Masalah penyakit pada hutan rakyat sementara ini informasinya masih relatif sedikit, padahal masalah penyakit dalam sektor kehutanan perlu mendapat perhatian yang lebih serius, karena tidak akan mungkin diperoleh suatu tegakan atau tanaman hutan yang sehat apabila masalah penyakit diabaikan. Penelitian ini bertujuan untuk mengidentifikasi penyakit tanaman (khususnya jati dan akasia) pada hutan rakyat di Kabupaten Wonogiri, Jawa Tengah. Proses identifikasi penyakit ini merupakan langkah pertama yang dilakukan
\end{abstract}


untuk nantinya mengambil tindakan dalam pengendalian penyakit. Hasil identifikasi menunjukkan bahwa tanaman jati terserang oleh penyakit layu yang disebabkan oleh bakteri Pseudomonas tectonae (Ralstonia solanacearum). Acacia auriculiformis terserang penyakit embun jelaga disebabkan oleh fungi Meliola sp., penyakit karat daun disebabkan oleh fungi Atelocauda digitata dan penyakit embun tepung disebabkan oleh Oidium sp. Ketiga fungi yang menyerang A. auriculiformis bersifat parasit obligat.

\section{Kata Kunci : Hutan rakyat, identifikasi penyakit, penyakit jati, penyakit akasia}

\section{PENDAHULUAN}

Pembangunan hutan rakyat merupakan program nasional yang sangat strategis, baik ditinjau dari kepentingan nasional maupun dari segi pandangan global, meliputi aspek ekonomi, ekologi maupun sosial budaya. Perkembangan hutan rakyat saat ini cukup pesat terutama setelah pasar kayu semakin baik dan didukung oleh minat petani untuk menanam jenis kayu-kayuan sangat tinggi, sehingga terlihat adanya sentrasentra budidaya tanaman hutan rakyat yang telah berkembang baik di Jawa maupun di luar Jawa (Mindawati dkk., 2006).

Salah satu kabupaten yang sudah sejak lama mengembangkan hutan rakyat yaitu Kabupaten Wonogiri. Di Wonogiri hutan rakyat diperkenalkan sejak adanya program "Karang Kitri" atau proyek rencana kesejahteraan istimewa sekitar tahun 1960-an (Anonim, 1995 dalam Donie, 1996). Usaha ini bertujuan untuk menghijaukan pekarangan, talun, lahan-lahan rakyat yang gundul, juga untuk konservasi tanah dan air serta perbaikan lingkungan. Selain itu diarahkan untuk mencapai sasaran peningkatan sosial ekonomi atau kesejahteraan masyarakat di pedesaan dan kebutuhan bahan baku kayu. Sejak adanya
"Proyek Inpres Penghijauan" tahun 1976/1977 dan program "Gerakan Nasional Rehabilitasi Hutan dan Lahan" (GNRHL/Gerhan) pada tahun 2003, kegiatan penanaman hutan rakyat semakin marak dan sampai saat ini berkembang menjadi hutan swadaya. Di Kabupaten Wonogiri luas hutan rakyat pada tahun 2005 mencapai 27.433 hektar yang tersebar di 25 kecamatan (Dinas Lingkungan Hidup, Kehutanan dan Pertambangan Kabupaten Wonogiri, 2005).

Jenis tanaman hutan yang dikembangkan di hutan rakyat Kabupaten Wonogiri antara lain jati (Tectona grandis L.f.), akasia (Acacia auriculiformis A. Cunn.), pinus (Pinus merkusii Jungh et De Vriese), sengon (Paraserianthes falcataria Backer.), mahoni (Swietenia macrophylla King.), cendana (Santalum album L.) yang dicampur dengan tanaman pertanian/perkebunan seperti jambu mete (Anacardium occidentale L.), ubi kayu (Manihot utilissima Pohl.), kacang tanah (Arachis hipogaea L.) dan jagung (Zea mays L.). Jenis jati merupakan yang dominan diantara 6 jenis tanaman hutan yang dikembangkan tersebut (Dinas Lingkungan Hidup, Kehutanan dan Pertambangan Kabupaten Wonogiri, 2005).

Jenis pohon yang dikembangkan pada hutan rakyat umumnya sama dengan jenis pohon yang 
dikembangkan pada hutan tanaman yaitu jenis pohon cepat tumbuh dengan pola tanam monokultur atau tumpangsari dengan tanaman pertanian. Hutan rakyat juga merupakan suatu ekologi binaan dengan budidaya pohon hutan yang sudah seharusnya menerapkan silvikultur intensif. Sehingga pada setiap pengusahaan hutan rakyat ada resiko penyakit. Masalah penyakit pada hutan rakyat sementara ini informasinya masih relatif sedikit. Masalah penyakit tanaman dalam sektor kehutanan perlu mendapat perhatian yang lebih serius, karena tidak akan mungkin diperoleh suatu tegakan atau tanaman hutan yang sehat apabila masalah penyakit diabaikan. Atas dasar hal tersebut di atas maka perlu adanya kajian aspek penyakit di hutan rakyat yang meliputi jenis patogen dan ekobiologi patogen, sehingga dapat sebagai pedoman untuk pencegahan dan pengendalian yang tepat.

Penelitian ini bertujuan untuk mengidentifikasi penyakit tanaman (khususnya jati dan akasia) pada hutan rakyat di Kabupaten Wonogiri, Jawa Tengah. Proses identifikasi penyakit ini merupakan langkah awal yang dilakukan untuk nantinya mengambil tindakan dalam pengendalian penyakit.

\section{BAHAN DAN METODE}

\section{A. Lokasi Penelitian}

Penelitian dilakukan di hutan rakyat di 5 kecamatan (Batuwarno, Baturetno, Pracimantoro, Giritontro dan Nguntoronadi) yang termasuk wilayah Kabupaten Wonogiri, Jawa Tengah. Kabupaten Wonogiri terbagi menjadi 25 Kecamatan yang terdiri dari 240 desa, dan merupakan kabupaten terluas kedua di Jawa Tengah (Dinas Lingkungan Hidup, Kehutanan dan Pertambangan Kabupaten Wonogiri, 2005). Tanaman hutan yang ada di hutan rakyat Kabupaten Wonogiri ada 6 jenis akan tetapi baru 2 jenis yaitu jati dan akasia saja yang menjadi obyek pengamatan.

Wilayah Kabupaten Wonogiri memiliki bentuk topografi mulai dari datar sampai bergunung dengan elevasi terendah $127 \mathrm{~m} \mathrm{dpl}$ dan tertinggi mencapai $1.300 \mathrm{~m}$ dpl. Kelerengan cukup bervariasi, yaitu 0 - $8 \%$ mencapai $39,4 \%, 8$ $-15 \%$ mencapai $15,26 \%, 15$ - 25\% mencapai $21,6 \%, 25$ - $45 \%$ mencapai $11,36 \%$ dan lebih dari $45 \%$ mencapai $12,27 \%$. Jenis tanah meliputi jenis litosol, grumosol, latosol, dan mediteran, dengan batuan vulkanik, batuan kapur dan batuan peralihan vulkanik dengan kapur.

\section{B. Bahan dan Alat}

Bahan-bahan yang digunakan dalam penelitian ini antara lain terdiri dari media biakan agar kentang atau PDA (Potatoes Dextrose Agar), alkohol 70\%, akuades steril, kapas, kertas saring, kertas hisap, kertas tissue, kertas koran, aluminium foil, dan kertas label.

Alat-alat yang digunakan dalam penelitian ini antara lain pustaka/referensi pengenalan penyakit tanaman, alat pemotong (gunting, silet, pisau/cutter), pinset, loupe, jarum ose, kaca obyek, kaca penutup, tabung reaksi, labu Erlenmeyer, lampu bunsen, cawan petri, oven, otoklaf, foto-mikroskop, ruang isolasi (LAF: Laminary Air Flow), dan kamera. 


\section{Metode Penelitian}

Sesuai dengan relevansinya masalah yang ingin diketahui adalah jenis patogen yang menyerang jati dan akasia di hutan rakyat Kabupaten Wonogiri. Cara pengamatan penyakit di lapangan adalah "case study" pada jati dan akasia. Penelitian dilakukan dengan cara diagnosis secara langsung yaitu dengan pengamatan gejala dan tanda yang khas yang ditunjukkan oleh penyakit di lapangan. Selanjutnya pemeriksaan dilakukan menggunakan lensa tangan (loupe), untuk mengetahui adanya spora fungi, cairan eksudat bakteria atau ciri-ciri yang lain (Streets, 1980). Apabila pada saat melakukan diagnosis secara langsung di lapangan tidak diketahui penyebab penyakitnya maka dilakukan Isolasi patogen. Sebelum melakukan isolasi perlu dipersiapkan media biakan PDA (media agar kentang/Potatox Dextrose Agar). Apabila pada pengamatan makroskopis sudah dapat diketahui patogen penyebabnya maka dilakukan pengamatan secara mikroskopis dengan cara pembuatan preparat sementara. Caranya dengan meletakkan irisan tipis transparan dari bahan tanaman/ material yang segar (bagian tanaman yang terserang penyakit) di atas gelas objek yang telah diberi setetes air, lalu ditutup dengan kaca penutup secara perlahan sedemikian rupa agar tidak terjadi gelembung udara dan diamati bawah mikroskop. Pengamatan secara mikroskopis ini dapat memperlihatkan ciri-ciri khas dari patogen seperti bentuk hifa, bentuk spora, bentuk tubuh buah dll.

Menghitung persentase kejadian penyakit (kejadian penyakit yaitu proporsi tanamantanaman yang terserang penyakit dalam suatu populasi tanaman tertentu, tanpa memper- hitungkan berat atau ringannya tingkat serangan) dengan rumus :

Persentase $=\frac{\text { Jumlah tanaman yang diserang }}{\text { Jumlah tanaman total yang diamati }} \times 100 \%$

\section{HASIL DAN PEMBAHASAN}

\section{A. Lokasi dan Serangan Penyakit}

\section{Kecamatan Batuwarno}

Luas hutan rakyat di Kecamatan Batuwarno seluruhnya 1.638 ha dengan jumlah tanaman kayu-kayuan 450 batang per ha. Jenis tanaman hutan yang ditanam adalah jati ( $T$. grandis L.f.) (tahun tanam 2003) yang dicampur dengan jenis tanaman pertanian seperti jambu mete $(A$. occidentale L.), ubi kayu (M. utilissima Pohl.) dan kacang tanah (A. hipogaea L.). Jarak tanam jati tidak beraturan, ada yang $1 \mathrm{~m} \times 2 \mathrm{~m}$ dan $3 \mathrm{~m}$ x $3 \mathrm{~m}$. Penyakit yang menyerang jati adalah penyakit layu dengan persentase serangan sebesar $6 \%$ dari 100 pohon yang diamati.

\section{Kecamatan Baturetno}

Luas hutan rakyat di Kecamatan Baturetno seluruhnya adalah 603 ha dengan jumlah tanaman kayu-kayuan 500 batang per ha. Jenis tanaman hutan yang ditanam terdiri dari Mahoni $(S$. macrophylla King.), Akasia (A. auriiculiformis A. Cunn.) yang dicampur dengan jambu mete ( $A$. occidentale L.) dan ubi kayu (M. utilissima Pohl.) dengan jarak tanam tidak beraturan. Penyakit yang menyerang $A$. auriculiformis terdiri dari penyakit embun jelaga, embun tepung dan karat daun sekaligus dalam satu pohon dengan persentase serangan dapat dilihat pada Tabel 1 . 
Tabel 1. Persentase serangan penyakit pada Akasia.

\begin{tabular}{|c|c|c|c|}
\hline No. plot & $\begin{array}{c}\text { Jumlah pohon yang } \\
\text { diamati }\end{array}$ & Penyakit & $\begin{array}{c}\text { Persentase serangan } \\
(\%)\end{array}$ \\
\hline \multirow[t]{3}{*}{1} & \multirow[t]{3}{*}{100} & A (Karat daun) & 100 \\
\hline & & B (embun jelaga) & 47 \\
\hline & & $\mathrm{C}$ (embun tepung & 5 \\
\hline \multirow[t]{3}{*}{2} & \multirow[t]{3}{*}{100} & A (Karat daun) & 100 \\
\hline & & B (embun jelaga) & 30 \\
\hline & & $\mathrm{C}$ (embun tepung & - \\
\hline \multirow[t]{3}{*}{3} & \multirow[t]{3}{*}{100} & A (Karat daun) & 80 \\
\hline & & B (embun jelaga) & 20 \\
\hline & & $\mathrm{C}$ (embun tepung & - \\
\hline \multirow[t]{3}{*}{4} & \multirow[t]{3}{*}{100} & A (Karat daun) & 90 \\
\hline & & B (embun jelaga) & 90 \\
\hline & & $\mathrm{C}$ (embun tepung & 10 \\
\hline \multirow[t]{3}{*}{5} & \multirow[t]{3}{*}{100} & $\mathrm{~A}$ (Karat daun) & 100 \\
\hline & & B (embun jelaga) & 2 \\
\hline & & $\mathrm{C}$ (embun tepung & 2 \\
\hline \multirow[t]{3}{*}{6} & \multirow[t]{3}{*}{100} & $\mathrm{~A}$ (Karat daun) & 100 \\
\hline & & B (embun jelaga) & 100 \\
\hline & & $\mathrm{C}$ (embun tepung & - \\
\hline \multirow[t]{3}{*}{7} & \multirow[t]{3}{*}{100} & $\mathrm{~A}$ (Karat daun) & 100 \\
\hline & & B (embun jelaga) & 100 \\
\hline & & $\mathrm{C}$ (embun tepung & - \\
\hline \multirow[t]{3}{*}{8} & \multirow[t]{3}{*}{100} & $\mathrm{~A}$ (Karat daun) & 100 \\
\hline & & B (embun jelaga) & 100 \\
\hline & & $\mathrm{C}$ (embun tepung & - \\
\hline \multirow[t]{3}{*}{9} & \multirow[t]{3}{*}{100} & $\mathrm{~A}$ (Karat daun) & 100 \\
\hline & & B (embun jelaga) & 100 \\
\hline & & $\mathrm{C}$ (embun tepung & - \\
\hline \multirow[t]{3}{*}{10} & \multirow[t]{3}{*}{100} & A (Karat daun) & 100 \\
\hline & & B (embun jelaga) & 100 \\
\hline & & $\mathrm{C}$ (embun tepung & - \\
\hline \multirow[t]{3}{*}{$\Sigma$} & \multirow[t]{3}{*}{1000} & A (Karat daun) & 970 \\
\hline & & B (embun jelaga) & 689 \\
\hline & & $\mathrm{C}$ (embun tepung & 17 \\
\hline
\end{tabular}

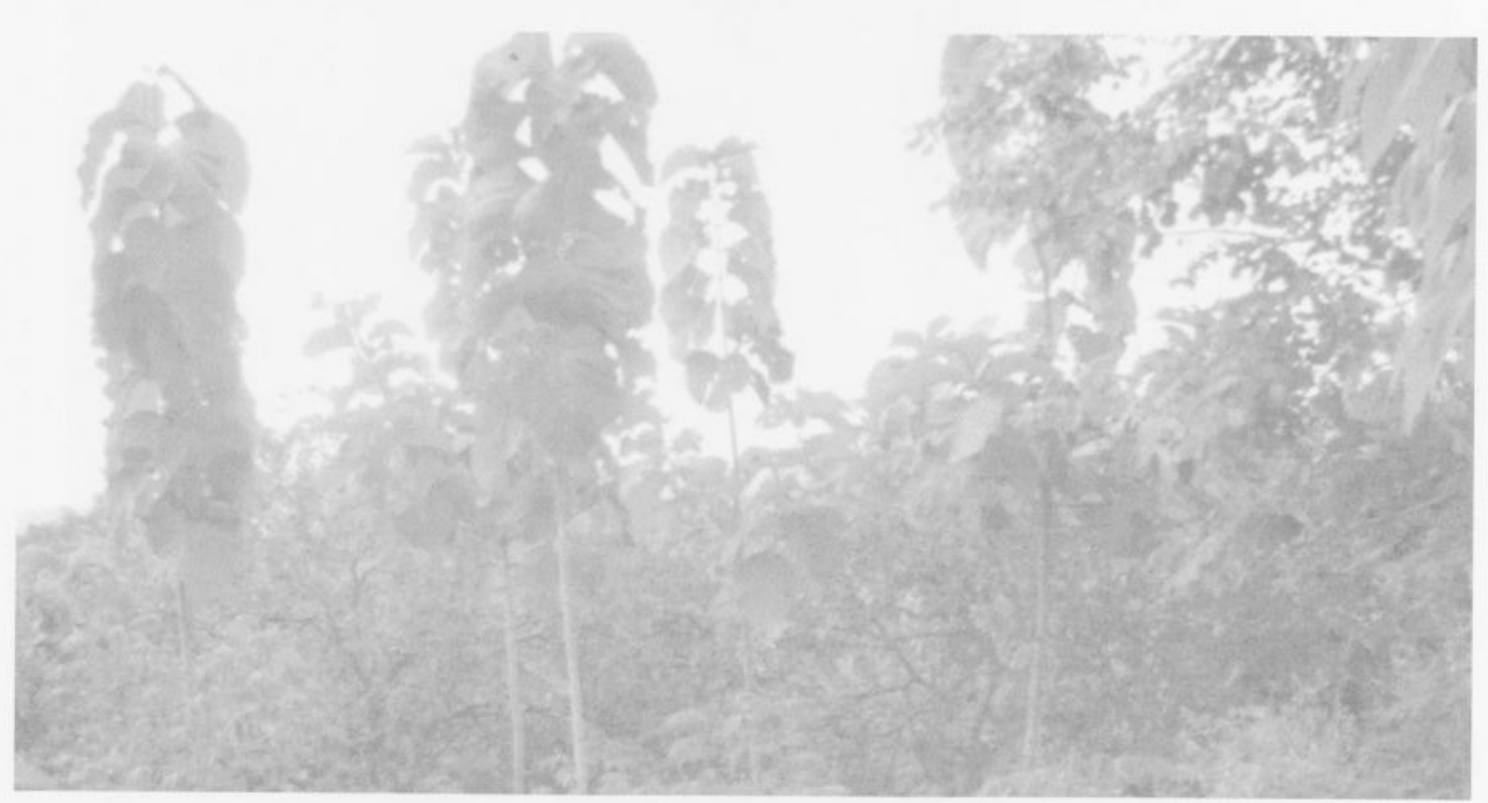

Gambar 1. Hutan rakyat di Kecamatan Batuwarno (Foto : Illa Anggraeni). 


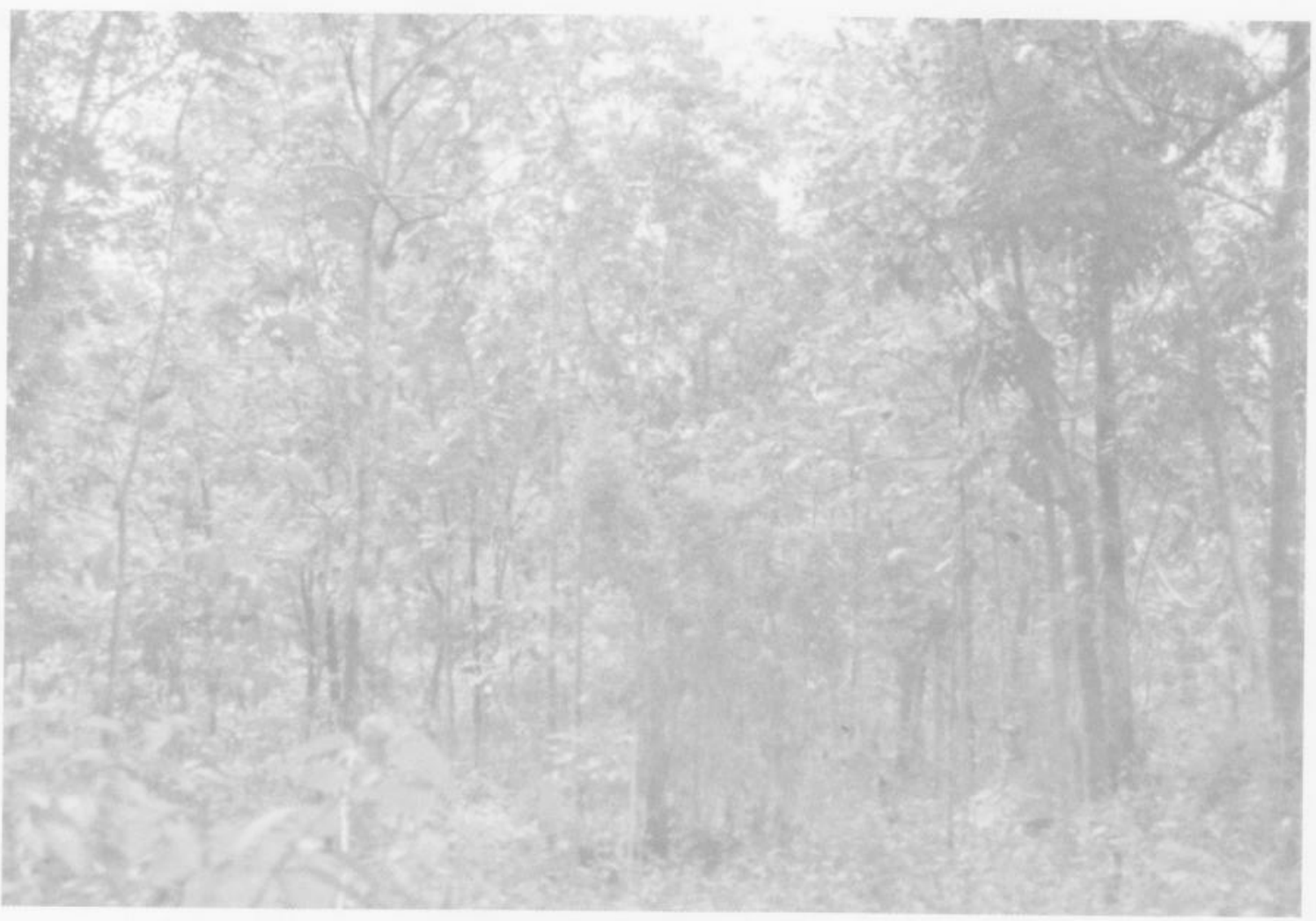

Gambar 2. Hutan rakyat di Kecamatan Baturetno. (Foto : Illa Anggraeni)

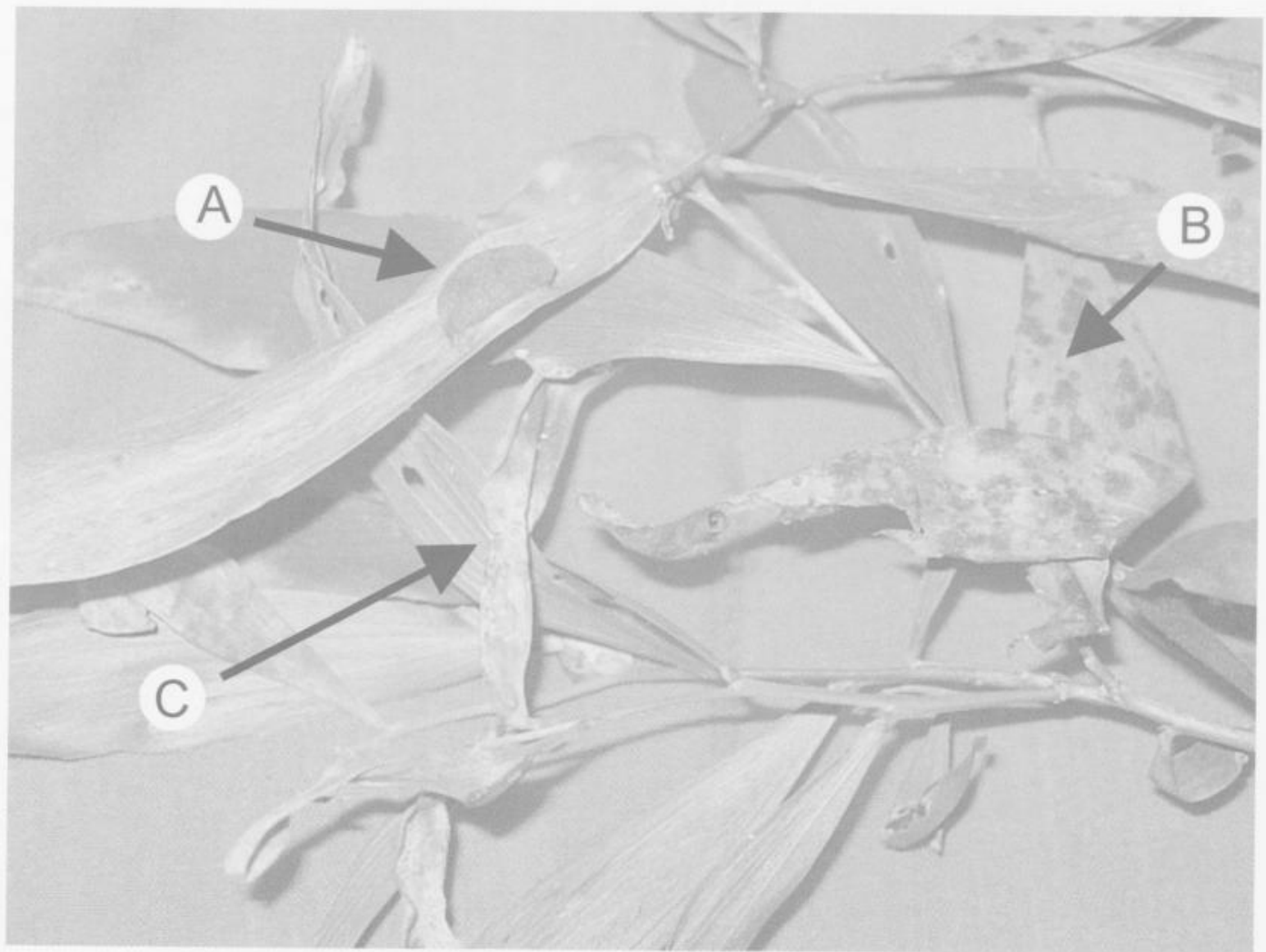

Gambar 3. Gejala karat daun (A), embun jelaga (B), dan embun tepung (C) pada akasia (Foto : Illa Anggraeni) 


\section{Kecamatan Nguntoronadi}

Luas hutan rakyat di Kecamatan Nguntoronadi seluruhnya adalah 795 ha dengan jumlah tanaman kayu-kayuan 400 batang per ha. Jenis tanaman adalah Jati (T. grandis L.f) (tahun tanam 2005) yang dicampur dengan dengan jambu mete (A. occidentale L.), ubi kayu (M. utilissima Pohl.) dan kacang tanah (A. hipogaea L.) dengan jarak tanam tidak beraturan.

Penyakit yang menyerang jati (T. grandis L.f) adalah penyakit layu dengan persentase serangan sebesar 5\% dari 100 pohon yang diamati.

\section{Kecamatan Giritontro}

Luas hutan rakyat di Kecamatan Giritontro seluruhnya adalah 2.463 ha dengan jumlah tanaman kayu-kayuan 500 batang per ha. Jenis tanaman adalah Jati ( $T$. grandis L.f.) (tahun tanam 2004) yang dicampur dengan dengan ubi kayu (M. utilissima Pohl.) dan kacang tanah (A. hipogea L.). Jarak tanam $2 \mathrm{~m}$ x $2 \mathrm{~m}$ dan tidak beraturan.

Penyakit yang menyerang jati adalah penyakit layu dengan persentase serangan sebesar $2 \%$ dari 100 pohon yang diamati.

5. Kecamatan Pracimantoro

Luas hutan rakyat di Kecamatan Pracimantoro seluruhnya adalah 3.958 ha dengan jumlah tanaman kayu-kayuan 550 batang per ha. Jenis tanaman adalah Jati (T. grandis L.f.) (tahun tanam 2000 dan 2004) dan akasia (A. auriculiformis A. Cunn.) yang dicampur dengan ubi kayu (M. utilissima Pohl.) dan kacang tanah (A. hipogea L.), jarak tanam tidak beraturan.

Penyakit yang menyerang $A$. auriculiformis adalah embun jelaga yang disebabkan oleh Meliola sp. dengan persentase $100 \%$ dari 100 pohon yang diamati.

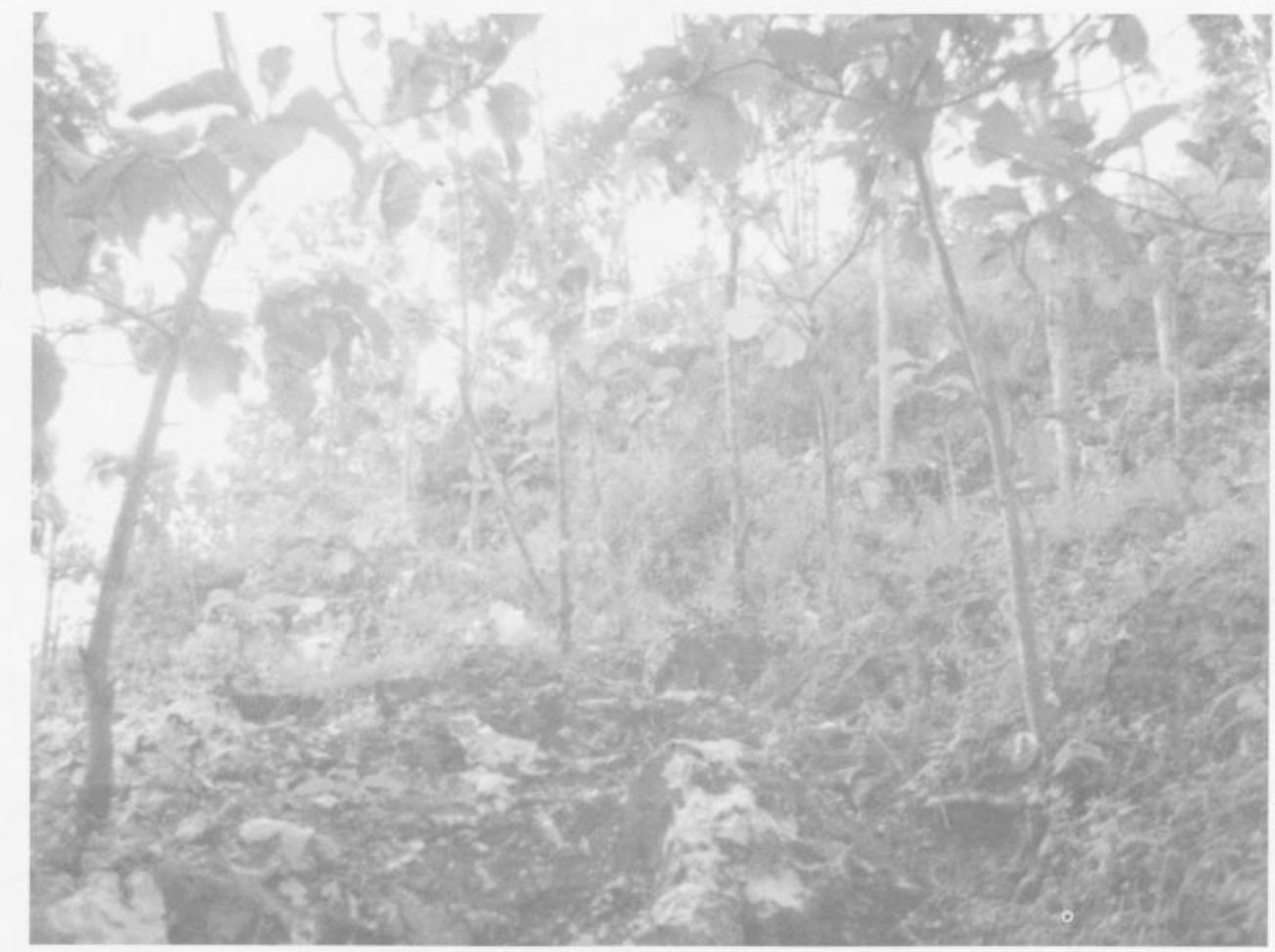

Gambar 4. Hutan rakyat di Kecamatan Nguntoronadi. (Foto : Illa Anggraeni) 


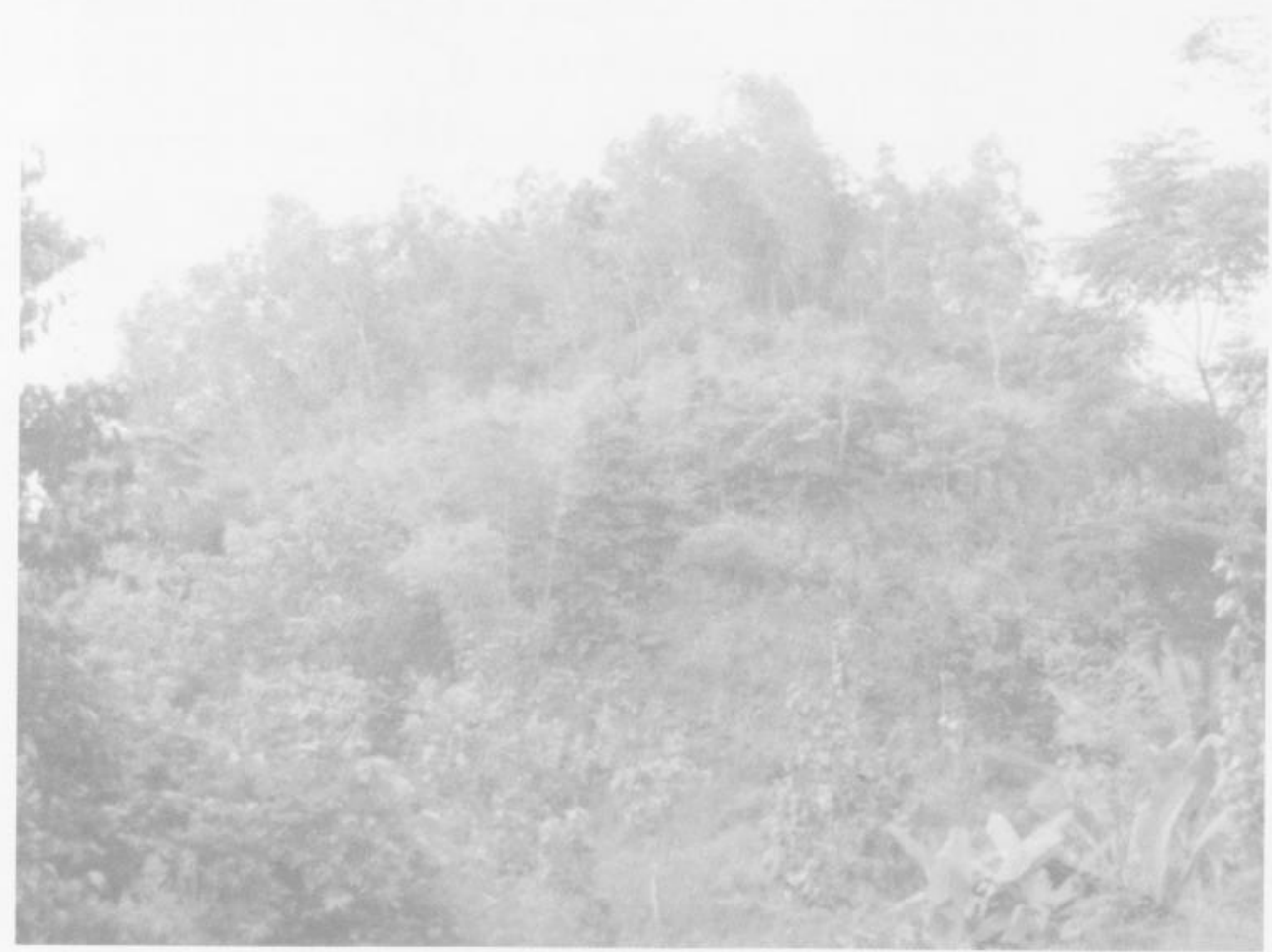

Gambar 5. Hutan rakyat di Kecamatan Pracimantoro. (Foto : Illa Anggraeni)

\section{B. Gejala Penyakit}

\section{Penyakit Layu}

Gejala penyakit layu pada jati diawali dengan timbulnya kelayuan, kelayuan ini bisa secara temporer atau permanen. Kelayuan temporer yaitu kelayuan yang hanya tampak pada siang hari dan sore harinya tanaman kembali segar, sedangkan kelayuan permanen yaitu tanaman menampakkan gejala layu seterusnya. Layunya bagian daun dapat serentak ataupun perlahanlahan, dimulai dari bagian daun tua atau pucuk lama kelamaan seluruh daun layu dan berwarna kuning kecoklat-coklatan dan menghitam seperti terbakar, daun luruh yang diikuti dengan kematian tanaman dalaim waktu yang relatif singkat (Gb. 6A). Apabila tanaman yang telah mati tersebut dicabut, akan tampak pada bagian pangkal batang dan akarnya agak menghitam dan membusuk, warna hitam ini juga terlihat pada bagian kayu
(Gb. 6B). Bila dipotong secara melintang tampak berkas-berkas pembuluh berwarna coklat kehitam-hitaman, apabila dipotong secara membujur berkas-berkas pembuluh tampak seperti garis coklat.

Tanaman yang telah terinfeksi oleh bakteri layu dapat menunjukkan perkembangan penyakit secara cepat dan juga dapat secara lambat. Apabila perkembangan penyakit berlangsung secara cepat gejala serangan akan menimbulkan layu yang menyeluruh, yaitu sebagian dari daun atau batang tampak seperti disiram air panas. Kelayuan ini dengan cepat meluas ke seluruh bagian tanaman. Tetapi apabila perkembangan penyakit berlangsung lambat maka gejala yang tampak adalah adanya perubahan warna daun menjadi pucat diikuti dengan adanya bercakbercak kuning kecoklatan berjumlah sedikit yang ukuran bercaknya bervariasi, lama kelamaan bercak makin banyak tersebar pada seluruh 

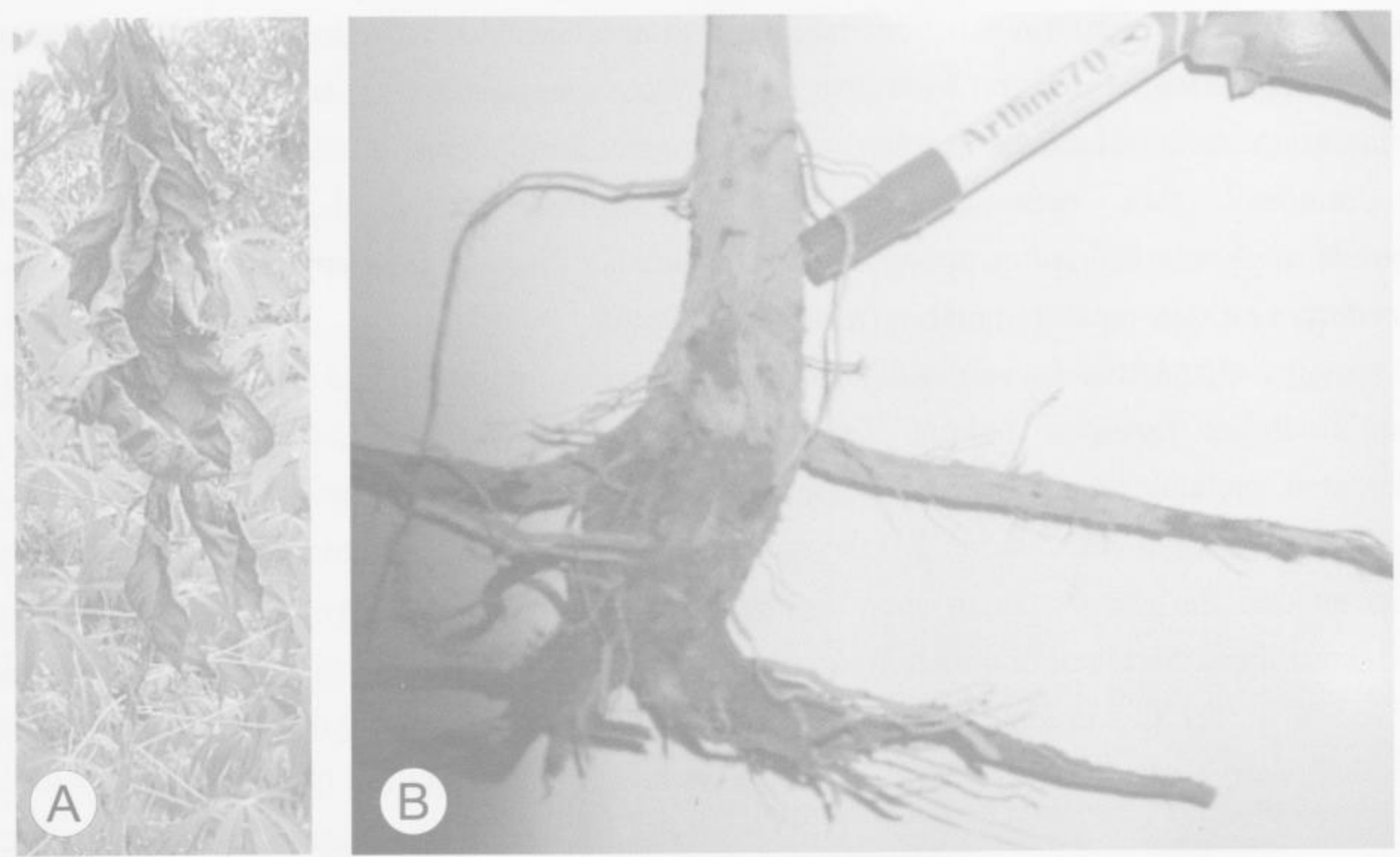

Gambar 6. Gejala penyakit layu bakteri. (Foto : Illa Anggraeni)
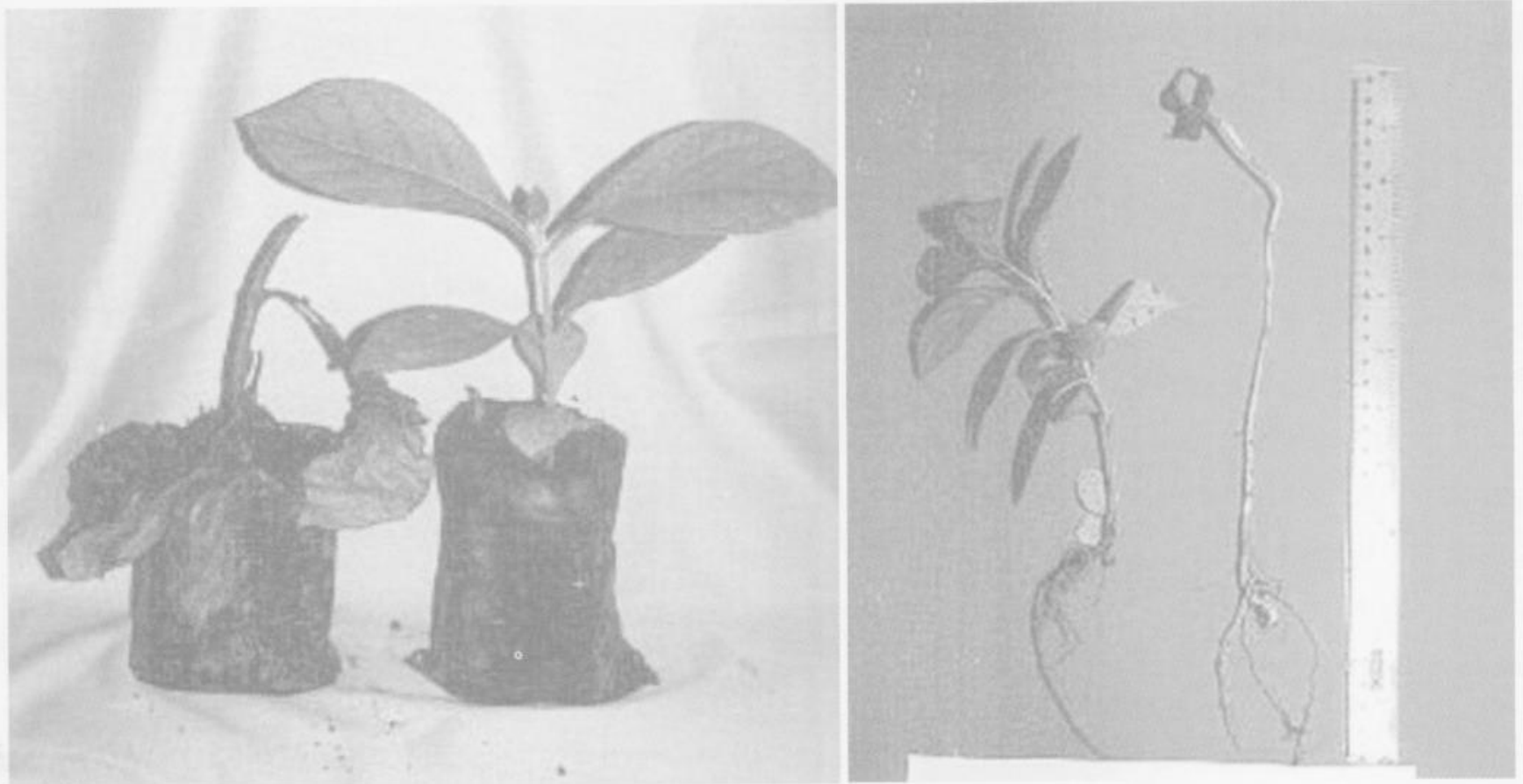

Gambar 7. Gejala penyakit layu bakteri pada bibit Jati. (Foto : Illa Anggraeni)

permukaan daun, akhirnya daun menguning, tanaman terhambat, beberapa hari kemudian tulang daun menjadi lemas dan terkulai. Akibat daun menjadi kering yang diikuti dengan serangan penyakit layu bakteri ini pertumbuhan perubahan daun menjadi gelap seperti terbakar. 
Dalam waktu yang relatif singkat bibit maupun tanaman muda mati kering. Kelayuan dan kekeringan tanaman diakibatkan oleh bakteri yang merusak dan menyumbat jaringan pembuluh angkut sehingga penyaluran bahan makanan dan air dari tanah terhambat (Mitchell, 1962 dalam Suharti dan Intari, 1974). Infeksi bakteri ke dalam tanaman melalui akar yang terluka atau melalui tanaman inang perantara yang ada di sekitarnya. Penyebaran bakteri dapat melalui air dan alat-alat pertanian yang digunakan. Bakteri dapat bertahan di dalam tanah pada suhu $30,5^{\circ} \mathrm{C}-36,1^{\circ} \mathrm{C}$ dan suhu optimum untuk perkembangannya adalah $25^{\circ} \mathrm{C}-30^{\circ} \mathrm{C}$ (Rahayu, 1999).

Hasil identifikasi secara makroskopis dan mikroskopis penyakit layu disebabkan oleh bakteri Pseudomonas tectonae (Bacterium solanacearum atau Ralstonia solanacearum (Agrios, 2005)) yang termasuk dalam famili Pseudomonadaceae dan kelas Schizomycetes. Bakteri ini memiliki inang yang cukup banyak. Selain jati juga dapat menyerang tanaman lain seperti famili Solanaceae. Bakteri mempunyai bentuk batang dengan ujung agak membulat, tidak membentuk kapsul dan spora. Bakteri bergerak dengan bulu cambuk (flagel) yang terdapat di ujung, bersifat aerob dan gram negatif. Pada media agar koloni bakteri berwarna putih yang kemudian menjadi coklat (Agrios, 2005).

\section{Penyakit Embun Jelaga}

Gejala penyakit embun jelaga diawali dengan timbulnya noda hitam atau bercak-bercak hitam pada permukaan daun, kemudian bercak tadi menebal berdebu seperti jelaga. Bercak hitam tersebut merupakan kumpulan miselium yang menutupi permukaan daun dan tangkai daun (Gb. 8A). Pada tingkat serangan berat daun akan menjadi kuning dan gugur sebelum waktunya. Hasil identifikasi secara makroskopis dan mikroskopis penyebab penyakit embun jelaga adalah fungi Meliola spp. Meliola spp. termasuk famili Meliolaceae, ordo Meliolales, kelas Ascomycetes (Old et al., 2000). Fungi ini bersifat parasit obligat artinya tidak dapat diisolasi dan ditumbuhkan pada media buatan, hanya dapat hidup pada bagian tanaman yang masih hidup dan mengganggu jaringan tumbuhan inang dengan jalan mempenetrasi sel inang. Meliola sp. mempunyai hifa yang disebut dengan hipopodia (hifa yang mempunyai tonjolan-tonjolan di kedua sisi dan berfungsi sebagai alat untuk merekat dan absorpsi pada daun (Gb. 8B). Askokarp/askus (tubuh buah) disebut pula peritesium karena berbentuk agak bulat yang pada ujungnya terdapat ostiol (lubang untuk keluarnya spora), spora yang dibentuk dalam askokarp disebut askospora, berbentuk lonjong mempunyai warna coklat agak kehitaman, spora berseptat (Gb. 8C).

\section{Penyakit Embun Tepung}

Gejala penyakit embun tepung sangat mudah diketahui karena adanya lapisan putih seperti tepung di atas permukaan daun atau bagian tanaman lain yang terserang. Lapisan ini merupakan miselium, konidia dan konidofor dari fungi patogen. Penyakit embun tepung ini umumnya menyerang daun yang masih muda. Daun yang diserang penyakit embun tepung umumnya pada permukaan bagian atas. Permukaan daun yang terserang berwarna kuning, kemudian coklat atau hitam, dan daun akhirnya gugur. Daun-daun yang terserang hebat mengalami perubahan bentuk (malformasi) menjadi mengerut, keriting atau bergelombang, 
daun menjadi kering dan akhirnya rontok sebelum waktunya. Apabila pucuk daun yang terserang maka bagian tersebut dapat kehilangan daunnya dan selanjutnya terjadi kematian pucuk (die-back).

Penyebab penyakit embun tepung adalah fungi Oidium sp. (Gb. 9) masuk dalam famili Moniliaceae kelas Deuteromycetes. Apabila fase generatif dan vegetatif dari fungi ini sudah diketahui maka fungi masuk dalam famili Erysipheceae kelas Ascomycetes (Dwidjoseputro, 1978). Oidium sp. bersifat parasit obligat, mempunyai spora berbentuk seperti drum yang dihasilkan dalam jumlah banyak.
Penyebaran penyakit melalui angin, air, serangga dan kondisi lingkungan yang cukup lembab yang memungkinkan pertumbuhan dan perkembangan fungi menjadi lebih cepat. Apabila spora sudah berada pada permukaan tanaman inang maka spora segera akan berkecambah dan membentuk haustorium yang berfungsi untuk menyerap makanan dari sel inang (Old et al., 2000).

\section{Penyakit Karat daun}

Gejala penyakit karat daun ditunjukkan dengan adanya bercak nekrotik berbentuk agak bulat dengan warna hijau pucat, letaknya pada permukaan daun maupun pada tangkai daun dan
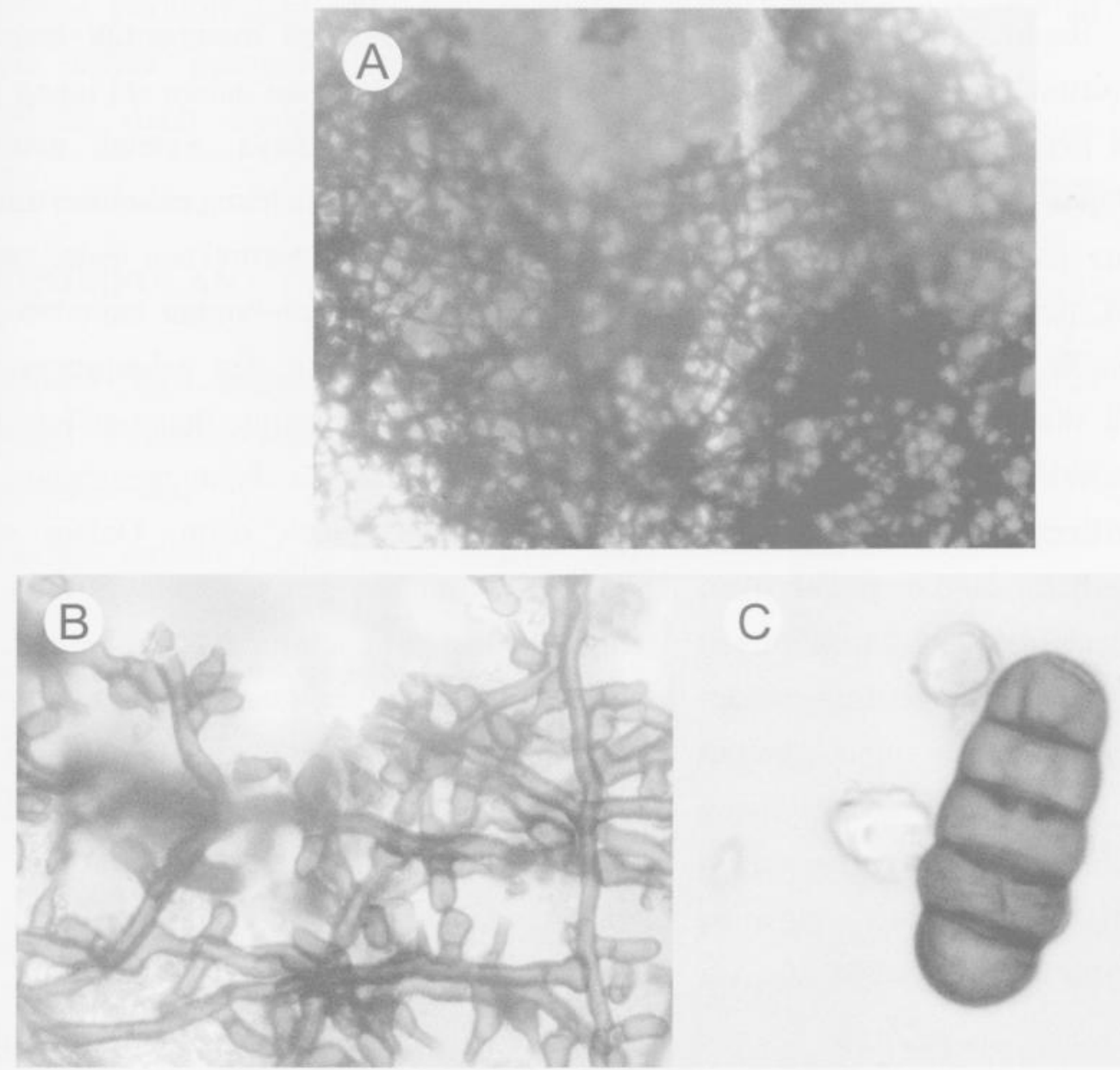

Gambar 8. (A). Embun jelaga pada daun A. Auriculiformis, (B). Hipopodia (hypopodia), dan (C). Askospora (ascospore). (Foto : Illa Anggraeni) 


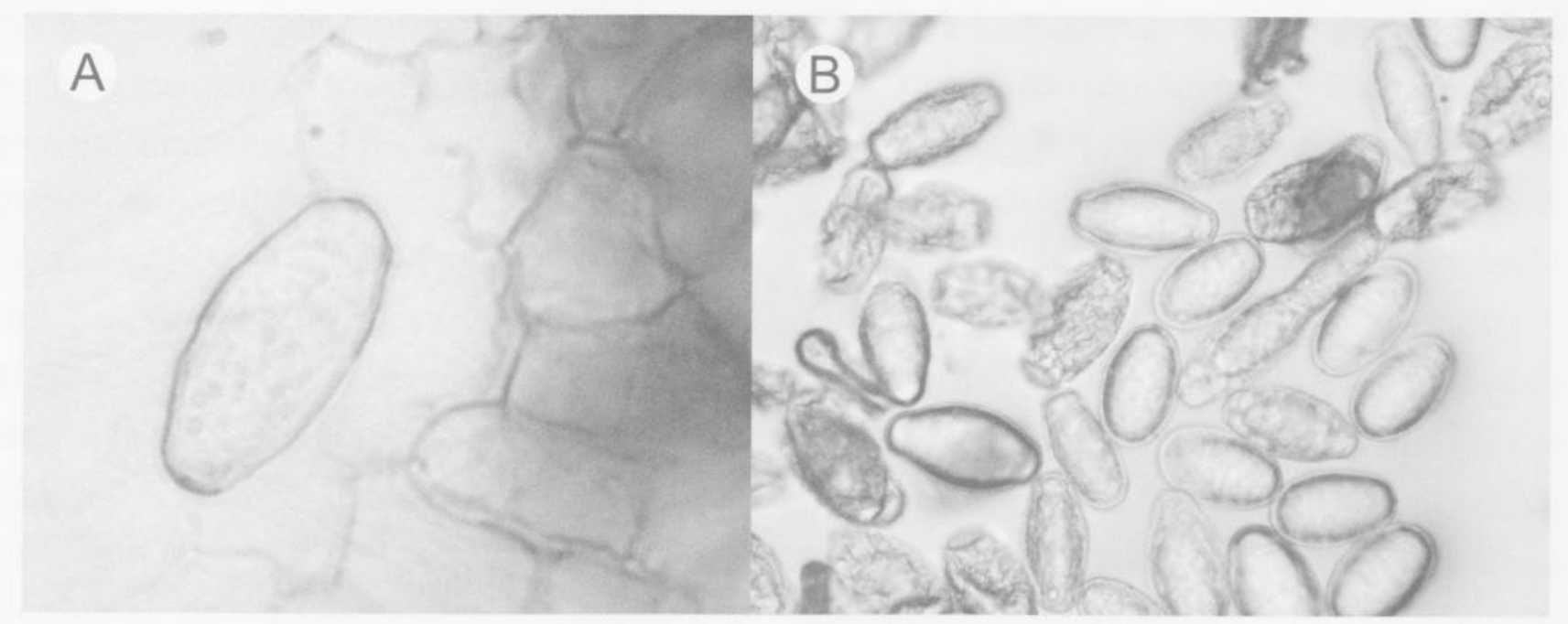

Gambar 9. (A). Konidia di atas permukaan daun (Conidiophores on leaf surface), (B). konidia (Conidiophore). (Foto : Illa Anggraeni

batang. Bercak nekrotik kemudian menebal dan membentuk pustul atau bintil/gall. Apabila pustul pada permukaan atas daun maka pada bagian permukaan daun akan membentuk cekungan. Besarnya pustul bervariasi dari berdiameter $1 \mathrm{~mm}$ sampai berdiameter $1 \mathrm{~cm}$. Pustul awalnya berwarna hijau pucat agak kekuningkuningan yang mana pada permukaan pustul tidak halus (seperti permukaan kulit jeruk) seperti ada bintik-bintik coklat, apabila pustul sudah tua warnanya menjadi coklat kehitamhitaman. Jumlah pustul yang terbentuk pada permukaan daun juga bervariasi dari 1 sampai 20 . Pada serangan yang berat bagian pucuk akan mengalami perubahan bentuk (malformasi) menjadi mengerut dan mengeriting, daun menghitam seperti hangus, daun gugur sebelum waktunya atau pada daun timbul lubang-lubang karena pustul luruh. Akibat dari serangan penyakit karat ini pertumbuhan tanaman terhambat, bahkan bibit/tanaman muda menjadi kering dan mati.

Hasil identifikasi secara makroskopis dan mikroskopis penyebab penyakit karat daun adalah Atelocauda digitata (Uromyces digitatus), fungi masuk dalam kelas Basidiomycetes dan famili Pucciniaceae. Fungi bersifat parasit obligat. Miselium fungi membentuk haustoria untuk menyerap makanan dalam sel inang guna melanjutkan kehidupannya. Setelah haustoria masuk ke dalam jaringan inang miselium tumbuh dengan baik di bawah permukaan daun, ranting atau batang serta bagian-bagian tanaman yang lain untuk berkembang dan selanjutnya akan membentuk spora. Miselium dapat meluas lebih jauh ke dalam jaringan dapat menembus akar atau tumbuh di pucuk daun. Dalam siklus hidupnya fungi patogen mempunyai lima fase dengan urutan yang teratur sebagai berikut, fase pembentukan piknium, fase pembentukan esium yang menghasilkan esiospora, fase pembentukan uredium menghasilkan uredospora, pembentukan telium menghasilkan teliospora dan fase terakhir adalah fase pembentukan promiselium dengan basidiospora.

Acacia auriculiformis yang terinfeksi patogen embun jelaga dan embun tepung sekaligus juga patogen karat daun memper- 


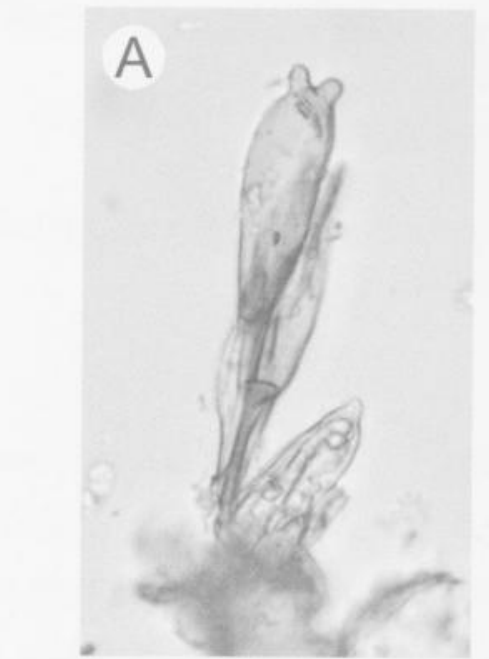

Gambar 10. (A). Teliospora (Teliospores), (Foto : Illa Anggraeni)

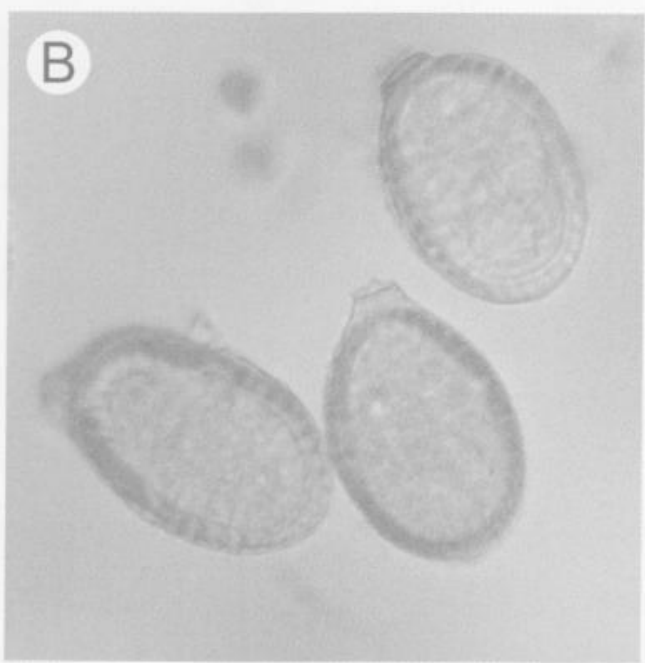

(B). Uredospora (Uredospores) lihatkan pertumbuhan yang terhambat, terjadi salah bentuk dan bahkan menimbulkan kematian. Terjadinya pertumbuhan yang lambat karena konidia kedua patogen yang tumbuh pada permukaan daun menghambat proses fotosintesa.

\section{KESIMPULAN}

1. Penyakit layu pada jati disebabkan oleh bakteri Pseudomonas tectonae (Ralstonia solanacearum).

2. Penyakit embun jelaga pada Acacia auriculiformis disebabkan oleh fungi Meliola sp.

3. Penyakit karat daun pada $A$. auriculiformis disebabkan oleh fungi Atelocauda digitata.

4. Penyakit embun tepung pada A. auriculiformis disebabkan oleh fungi Oidium sp.

\section{DAFTAR PUSTAKA}

Agrios, G.N. 2005. Plant Pathology. $5^{\text {th }}$ eds. Rahayu, S. 1999. Penyakit Tanaman Hutan di Elsevier Academic Press. USA.
Dinas Lingkungan Hidup, Kehutanan dan Pertambangan Kabupaten Wonogiri. 2005. Luas hutan rakyat di wilayah Kabupaten Wonogiri.

Donie, S. 1996. Kajian aspek kelembagaan pengusahaan hutan rakyat di DAS Solo. Proyek Penenlitian dan Pengembangan Teknologi Pengelolaan DAS Solo. Surakarta.

Dwidjoseputro, D. 1978. Pengantar Mikologi. Penerbit Alumni. Bandung.

Mindawati, N, AsmanahWidiarti, dan Budi Rustaman. 2006. Review Hasil Penenlitian. Hutan rakyat. Puslitbang Hutan Tanaman. Bogor.

Old, KM, Lee Su See, Jyoti K. Sharma and Zi Qing Yuan. 2000. A manual of diseases of tropical Acacias in Australia, South-east Asia and India. Center for International Forestry Research (CIFOR). Jakarta Indonesia (Gejala, penyebab, dan teknik 
pengendaliannya). Penerbit Kanisius.

Yogyakarta.

Streets, RB. 1980. Diagnosis penyakit tanaman (Buku manual untuk pedoman di lapangan maupun di laboratorium yang menitik beratkan pada metoda-metoda paling praktis guna identifikasi secara cepat. Alih Bahasa Dr. Iman Santoso). PT. Gede Jaya. Indonesia.

Suharti, M. Dan S.E. Intari. 1974. Pedoman pengenalan beberapa hama dan penyakit pada Jati (Tectona grandis L.f). Laporan No. 182 Lembaga Penelitian Hutan. Bogor. 